\title{
Haematological and blood biochemical changes induced by the administration of low doses of Escherichia coli lipopolysaccharide in rabbits
}

\author{
Cambios hematológicos y en la bioquímica sanguínea inducidos por la administración \\ de dosis bajas de lipopolisacárido de Escherichia coli en conejos
}

\author{
AK Peñaililloa , MA Sepulveda ${ }^{a}$, CJ Palma ${ }^{a}$, A Espinoza ${ }^{a}$, M Aguilera ${ }^{b}$, \\ RA Burgos ${ }^{\mathrm{c}}$, D Carretta $^{\mathrm{c}}$, A Islas ${ }^{\mathrm{b}}$, R Pérez $^{\mathrm{a}^{*}}$
}

\begin{abstract}
The aim was to investigate the haematological and blood biochemistry changes of adult rabbits after two intravenous administrations of low-doses of E. coli lipopolysacharide (LPS). Six clinically healthy rabbits were distributed through a cross over design to experimental groups: Group 1 (LPS) treated with two intravenous doses of $1 \mu \mathrm{g} / \mathrm{kg}$ bw of $E$. coli LPS at $6 \mathrm{~h}$ intervals. Group 2 (Control) treated with an equivalent volume of saline solution (SS) at similar intervals. Rectal temperature $\left(\mathrm{T}^{\circ} \mathrm{R}\right)$, serum concentrations of interleukin-6 (IL-6), C-reactive protein (CRP), haemogram, and the activity of enzymes aspartate aminotransferase (AST) and gamma glutamil transferase (GGT) were measured before and after LPS or SS administration. The administration of LPS in rabbits induced significant increases in IL-6 and CRP concentrations. Leukopenia associated to significant decreases of monocytes, lymphocytes and platelet count, with no significant changes in neutrophil count, were observed at 4 and $8 \mathrm{~h}$ after LPS administration. There were significant increases in total leukocytes and neutrophils count at 12 and $24 \mathrm{~h}$. No significant changes $(\mathrm{P}>0.05)$ were observed in mean values of PCV, total proteins, albumin and in the activity of enzymes AST and GGT. The administration of low doses of $E$. coli LPS induces a fast increase in body temperature, haematological and biochemical shifts, which are milder and have a lower intensity and shorter than previous reports in rabbits treated with high doses of LPS. These changes seem to be consistent with an initial inflammatory response induced by a gram-negative infection.

Key words: lipopolysaccharide, haematology, blood biochemistry, rabbits.
\end{abstract}

RESUMEN. El objetivo fue investigar los cambios hematológicos y en la bioquímica sanguínea inducidos por la administración de dosis bajas de lipopolisacárido de Escherichia coli (LPS) en conejos. Seis conejos clínicamente sanos fueron distribuidos en dos grupos experimentales mediante un diseño cruzado: Grupo 1 (LPS) tratado con dos dosis intravenosas de $1 \mu \mathrm{g} / \mathrm{kg}$ de LPS. Grupo 2 (Control) fue tratado con un volumen equivalente de solución salina (SS). Previo y posterior a la administración de LPS se midió temperatura rectal $\left({ }^{\circ} \mathrm{C}\right)$, se determinaron las concentraciones de interleukina 6 (IL-6), proteína C reactiva (PCR), además se realizó hemograma y se midió la actividad de las enzimas aspartato aminotransferasa (AST) y gamma glutamil transferasa (GGT). La administración de LPS produjo aumentos significativos en la temperatura rectal, IL-6 y PCR. A las 4 y 8 h posteriores a la inyección de LPS se observó leucopenia asociada a disminución en el recuento de monocitos, linfocitos y plaquetas, mientras que a las 12 y $24 \mathrm{~h}$ el recuento de leucocitos y neutrófilos aumentó significativamente. No se observaron cambios en los promedios de VGA, concentración de proteínas totales y albúmina o en la actividad de las enzimas AST y GGT. Se concluye que las modificaciones hematológicas y de bioquímica sanguínea inducidas por la administración de dosis bajas de LPS son de moderada intensidad y corta duración en comparación a las descritas en conejos tratados con dosis altas de LPS. Estos cambios son consistentes con un estado de respuesta inflamatoria inicial inducida por una infección por Gram negativos.

Palabras clave: lipopolisacárido, hematología, bioquímica sanguínea, conejos.

\section{INTRODUCTION}

The acute-phase response (APR) represent an early and highly complex reaction of the organism to a variety of injuries such as bacterial, viral or parasitic infections,

\footnotetext{
Accepted: 17.03.2016.

aLaboratorio de Farmacología, Departamento de Ciencias Clínicas, Facultad de Ciencias Veterinarias, Universidad de Concepción, Chillán, Chile.

bLaboratorio Clínico, Departamento de Ciencias Clínicas, Facultad de Ciencias Veterinarias, Universidad de Concepción, Chillán, Chile.

'Instituto de Farmacología. Facultad de Ciencias Veterinarias, Universidad Austral de Chile, Valdivia, Chile.

\#Financial support to carry out this research work was provided by Grant FONDECYT 1130473 from the National Council for Science and Technology (CONICYT-Chile).

*Corresponding author: R Pérez; PO Box 537, Chillán, Chile; rubperez@udec.cl
}

mechanical or thermal trauma, ischemic necrosis or malignant growth (van Miert 1990). A variety of changes in the organism acts in concert to neutralize the inflammatory agent and foster healing of damaged tissues (Ebersole and Capelli 2000).

The cell wall of gram-negative bacteria contains and release endotoxin (Raetz and Whitfield 2002), the major biologically active component of endotoxin is lipopolysaccharide (LPS) which is a potent inducer of inflammation (Hewett and Roth 1993). LPS has been used in scientific investigation for many years as a tool to induce and study inflammatory responses (Roth et al 1997). In rabbits and other different animal species, administration of endotoxin in vivo has been used commonly in the study of cellular and molecular host responses, to increase understanding of the mechanisms of the immune response to bacterial infection (Hodgson 
2006). The principal attractions of this model are: (1) its reproducibility, (2) its easiness to perform, and (3) the ability to delineate inflammatory/septic responses from other alterations caused by bacterial infections (Parker and Watkins 2001). Therefore, LPS has been used to study the impact of different anti-inflammatory agents and as a model for studying the impact of inflammation on various diseases, including drug pharmacokinetics (Myers et al 2003). The pathophysiological effects of endotoxins in the different species are predominantly dose-dependent. In general, as dose increases, latency time decreases, the peak effect becomes more pronounced, and the duration of the effects protracted (Lohuis et al 1988). It is known that responses to LPS are not directly caused by the toxicosis of LPS as they are induced by inflammatory mediators released from activated host cells (Jacobsen et al 2005).

Nowadays, research related with the APR induced by $E$. coli LPS in rabbits, have been performed mainly using high doses of LPS in order to reproduce the physio-pathological conditions of an endotoxic shock. In this way, Saitoh et al (1999) used five intravenous injections of $17 \mu \mathrm{g} / \mathrm{kg}$ of endotoxin at intervals of $1 \mathrm{~h}$ to induce an acute endotoxemia in rabbits. While Elmas et al (2006 ${ }^{\mathrm{a}}$, b) using an intravenous bolus of $100 \mu \mathrm{g} / \mathrm{kg}$ of $E$. coli LPS, induced an endotoxic shock characterised by hepatic and renal dysfunctions evidenced through a significant increases in AST, ALT and creatinine. However, the most common situation observed during gram negative induced APR, seems to be a gradual increase in the endotoxin levels which can produce haematological and blood biochemical modifications which could be different than those observed in animals under endotoxemic shock. Under this situation it is necessary to know the magnitude of the hematological and blood biochemical changes induced by low repeated doses of the gram-negative derivative lipopolysaccharide. The difficulty and expense associated with the development of actual bacterial infections models in animals has led to the use of LPS as surrogate when studying the physiopathological and clinical modifications induced by a bacterial infection. The underlying assumption of these studies is that resulting inflammation closely models an actual infection. The aim of the present study was to investigate the haematological and blood biochemistry changes observed in adult rabbits after two repeated intravenous administrations of low-doses of $E$. coli LPS.

\section{MATERIAL AND METHODS}

\section{ANIMALS}

A group of 6 male and female rabbits was used (6 - 8 months of age and $2.6-3.5 \mathrm{~kg}$ of body weight). All animals were clinically healthy and had not received any drugs within at least one month before the beginning of the study. All procedures were performed with the authorisation of the Ethical Committee for Animal Experimentation of the Faculty of Veterinary Sciences, Universidad de Concepción, Chile.

\section{EXPERIMENTAL DESIGN}

The rabbits were distributed by a $2 \times 2$ factorial design with two treatments and two periods considering a washout period of 10 days. Pairs of animals were assigned into 2 experimental groups receiving parallel control and experimental treatment with LPS. Group 1 (LPS), was treated with 2 intravenous (IV) doses of $1 \mu \mathrm{g} / \mathrm{kg}$ of Escherichia coli O128: B12 LPS (Sigma-Aldrich, St Louis, Missouri, USA) at intervals of 6 hours. The LPS dose was determined in a pre-experimental study searching for a dose that can increase body temperature in at least $+0.7{ }^{\circ} \mathrm{C}$. Group 2 (control) was treated with $2 \mathrm{IV}$ injections of an equivalent volume of $0.9 \%$ saline solution (SS) at intervals of $6 \mathrm{~h}$.

\section{BODY TEMPERATURE RECORDING AND BLOOD SAMPLES} PROCESSING

Rectal temperature $\left(\mathrm{T}^{\circ} \mathrm{R}\right)$ was monitored each $15 \mathrm{~min}$ by a multi - parameter monitor (Model MP800, Mekics Co. Ltd., Kanguando, Korea) for a period of $24 \mathrm{~h}$. Blood samples $(2 \mathrm{ml})$ were collected by puncture of the auricular vein before (T0) and at 4, 8, 12 and 24 hours after the first administration of LPS or SS. The samples were centrifuged at $3500 \mathrm{rpm}$ at $4{ }^{\circ} \mathrm{C}$ for 5 minutes to obtain serum, for determination of inflammatory markers and blood biochemistry. The concentrations of IL- 6 and CRP were determined by quantitative enzyme immunoassay (ELISA), using commercial kit for rabbits (IL-6: CUSABIO Biotech Co. Ltd. Wuhan, China; CPR: ALPCO, Salem, Massachusetts, USA). The concentrations of total proteins and albumin were measured using colorimetric methods. The activity of enzymes aspartate aminotransferase (AST) and gamma glutamil transferase (GGT) were determined by kinetic methods using commercial reagent kit (Wiener Lab, Rosario, Argentina) and measured by a spectrophotometer (Multiskan spectrophotometer GO, Thermo Scientific ${ }^{\circledR}$, Vantaa, Finland). White blood cell count was determined by traditional methods. PCV was determined by centrifugation of blood samples in a high speed micro-hematocrit centrifuge.

\section{STATISTICAL ANALYSIS}

Results are expressed as mean \pm standard deviation and compared using an ANOVA, associated to a Tukey-Kramer multiple comparison test. A P value 0.05 was established to determine significant differences between groups.

\section{RESULTS AND DISCUSSION}

The current study have characterised the APR induced by two repeated low doses of E. coli LPS administered by 
intravenous route in rabbits. The dose used was selected to reproduce a moderate APR, which could be observed at the beginning of some infections induced by gram-negative organisms in animals.

Intravenous administration of $1 \mu \mathrm{g} / \mathrm{kg}$ of LPS in rabbits produces significant increase in rectal temperature from a baseline of $39.7 \pm 0.6{ }^{\circ} \mathrm{C}$ to a maximum value of 41.4 $\pm 0.5^{\circ} \mathrm{C}$ observed at $2.5 \mathrm{~h}$, decreasing to values close to basal levels within the next $6 \mathrm{~h}\left(39.9 \pm 0.9^{\circ} \mathrm{C}\right)$ (figure 1). In control group, rectal temperature remained in the range of $39.1 \pm 0.6^{\circ} \mathrm{C}$ to $39.7 \pm 0.6^{\circ} \mathrm{C}$. After administration of the second dose of LPS, another increase in rectal temperature was observed, reaching values of $41.1 \pm 0.6$ at $1.5 \mathrm{~h}$ post-injection. Significant increases in serum concentrations of IL-6 and CRP (figure 1), were observed. Regarding to IL-6, an increase from basal values $(\mathrm{P}<0.05)$ was observed at 8
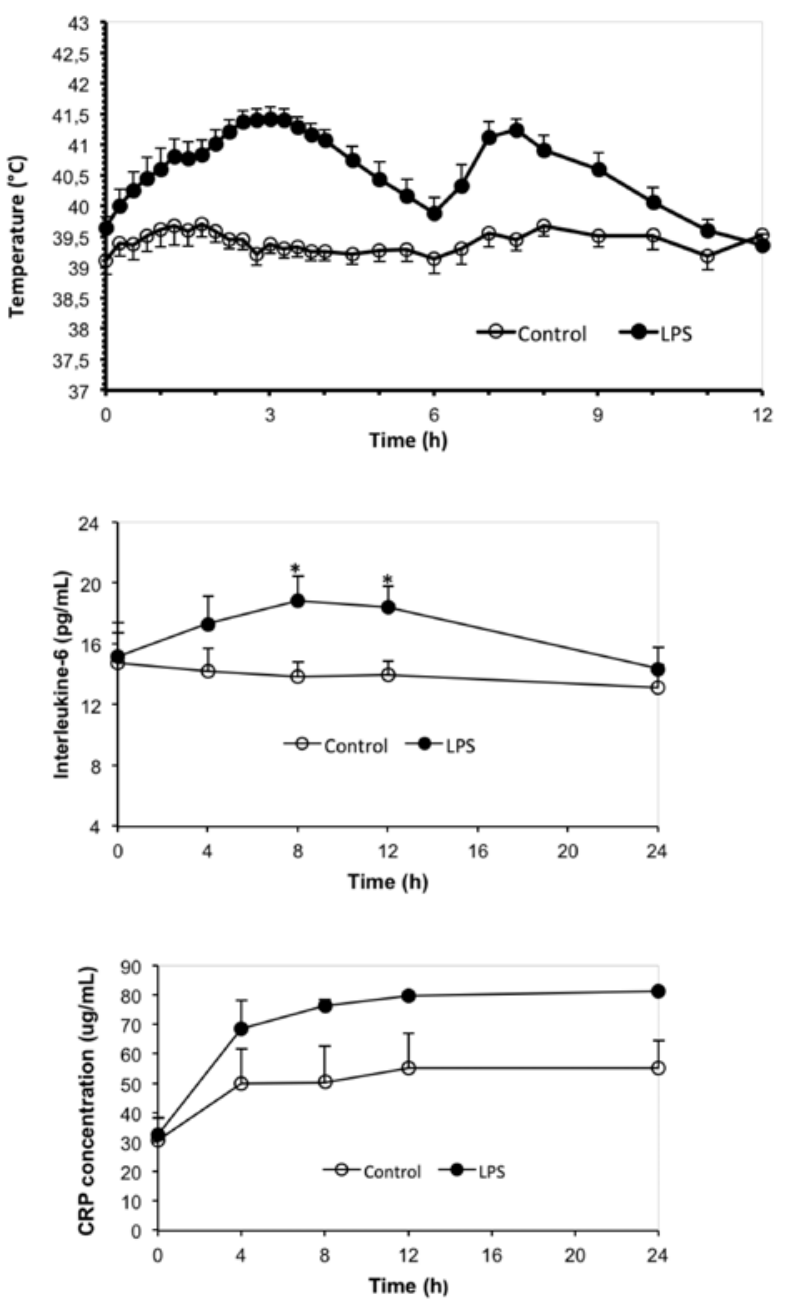

Figure 1. Mean values of rectal temperature, interleukin-6, and C-reactive protein in control and Escherichia coli LPS-treated rabbits. Values represent mean \pm SEM for $n=6$ rabbits.

Promedios de temperatura rectal, interleukina-6 (b) y proteína C-reactiva (c) en conejos control y tratados con lipopolisacárido de Escherichia coli. Valores representan el promedio \pm EEM para $\mathrm{n}=$ 6 conejos. and $12 \mathrm{~h}$ after LPS injection, and then decreased towards baseline values at $24 \mathrm{~h}$ (figure 1). It is known that IL-6 is one of the most important endogenous mediators of LPS fever inductors and their circulating levels shows the best correlation with febrile changes of body temperature (Roth et al 2006). In this way, changes observed in body temperature of rabbits of the current study are well related with the variations observed in plasma concentrations of IL-6. The mechanism through which IL-6 induces fever is the elevation of the thermoregulatory set point. Available evidence shows that IL- 6 act on thermoregulatory centers within the hypothalamus, stimulating prostaglandin E2 synthesis, which removes inhibition of thermo-sensitive neurons (Roth et al 2006).

Serum C-reactive protein concentrations follow closely the course of APR to inflammation or tissue necrosis (Ebersole and Capelli 2000). As observed in Figure 1, serum concentrations of CRP increased significantly 4 $\mathrm{h}$ after LPS administration and remain elevated at $24 \mathrm{~h}$, indicating that IV administration of LPS induced an APR that is sustained for at least a $24 \mathrm{~h}$ period. Similar results were reported by Saitoh et al (1999) in rabbits treated with five separate injections of $17 \mu \mathrm{g} / \mathrm{kg}$ of LPS at intervals of one hour, however due to high and repeated doses of LPS the CRP concentrations remained elevated for a period of 7 days.

Leukopenia associated with significant decreases of monocytes and lymphocytes counts, with no significant variations in the neutrophil count, were the most significant haematologic changes observed in samples taken at 4 and $8 \mathrm{~h}$ after the first administration of $E$. coli LPS. However, in samples taken at 12 and $24 \mathrm{~h}$ after the first injection of LPS, there was a significant increase in total leukocytes and neutrophils count (figure 2).

Inflammatory reactions are multicellular events that include chemotaxis, adhesion and controlled interactions among leukocytes, endothelial cells, and platelets on the blood vessel wall (Klinger and Jelkmann 2002). In this study, rabbits treated with endotoxin showed a biphasic modification on the total leukocytes count. In the first phase a mild leukopenia was observed in samples taken at $4 \mathrm{~h}$ after LPS injection. However, this effect was not observed after the second administration of endotoxin at $6 \mathrm{~h}$, indicating that rabbits can evidence some tolerance to repeated LPS administration. Leukopenia was associated to a reduction in the number of lymphocytes and monocytes, without changes in circulating neutrophils count. Although this response is comparable to that described by Deldar et al (1984) in neonatal calves, the rabbits of current work did not manifest significant changes in the circulating neutrophils count. Despite that leukopenia after LPS administration have been attributed to a rapid sequestering and loss of neutrophils from circulating blood in the pulmonary microcirculation (Duncan et al 1985, Ward et al 1987), this effect was not observed in the treated rabbits of current study. A short lasting neutropenia was observed 
by Koot et al (1989) in goats treated with an IV dose of $0.1 \mu \mathrm{g}$ LPS $/ \mathrm{kg}$. Probably, differences might arise from time of sampling, together with differences in sensitivity of species, age and doses of LPS used in rabbits of current work. The transient leukopenia observed in the first phase was followed by a rebound leukocytosis at 12 and $24 \mathrm{~h}$ after LPS injection, which was accompanied by an intense neutrophilia (figure 2). It is known that IL-6 stimulates corticotrophin release via activation of corticotrophin releasing hormone (CRF), and subsequently corticosteroid production, hence, this may indirectly lead to neutrophilia via corticosteroid-induced demargination and increased survival of neutrophils (Cox and Gauldie 1997).

A significant reduction in the lymphocytes cell count was observed at samples taken at 4 and $8 \mathrm{~h}$ after first injection of LPS in rabbits. These results are similar from those reported in horses treated with LPS, where lymphocyte counts values decreased over a period of 2 to 4 hours, depending on base line values and remaining for approximately a $50 \%$ of the base-line values during $24 \mathrm{~h}$ (Burrow 1979). In humans, monocytopenia and lymphopenia after administration of $E$. coli LPS was observed with a nadir of $1.5 \mathrm{~h}$ and $4 \mathrm{~h}$ respectively; monocyte count normalise within 6 to $8 \mathrm{~h}$ and lymphocyte count after 8-12 h (Andreasen et al 2008).

Blood platelets are a key element linking the processes of hemostasis, inflammation, and tissue repairing. Within a few seconds, platelets respond to specific signals generated on tissue injury or invasion by pathogens. Platelets are the first elements that accumulate at a site of damage of the vascular wall and within the surrounding tissue (Klinger and Jelkmann 2002). As is it observed in table 1, platelets count decreased significantly at samples taken at 4 and $8 \mathrm{~h}$ after LPS injection. Similar results were reported by Deldar et al (1984) in calves treated with LPS. The reduction in the platelet count is related to different factors such as: increased platelet aggregation produced by endotoxin; LPS induced damage to vascular endothelium and a direct activation of the coagulation system. These alterations could drive to platelets sequestration after endotoxin administration in the capillary beds of organs such as spleen, liver and lungs (Deldar et al 1984).

No significant changes were observed between the mean values of enzyme activities of AST and GGT, when both control and LPS groups of rabbits were compared. These results are different to those found by Elmas et al $\left(2006^{\mathrm{a}}\right)$ in rabbits treated with a high intravenous dose of $100 \mu \mathrm{g} /$ $\mathrm{kg}$ of LPS, where significant increases in the activity of AST and ALT were observed. Moreover, in another study, these researchers (Elmas et al 2006 ${ }^{\mathrm{b}}$ ) found that the same high dose and route of administration of LPS in rabbits produced significant increases in the activity of enzymes AST, ALT and GGT, accompanied by increases in mean values of serum creatinine and urea. They concluded that the high dose of LPS used can produce hepatic and renal damage. The responses observed are probably related mainly
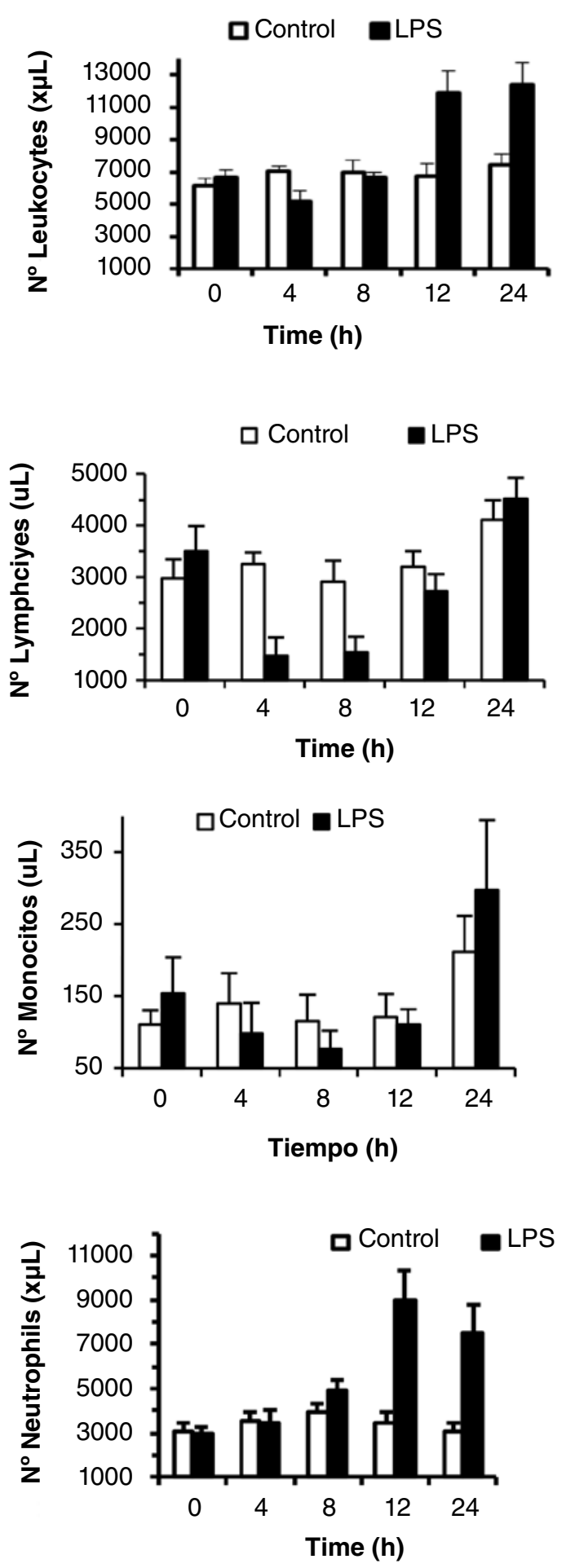

Figure 2. Mean values of total leukocytes, neutrophils, lymphocytes and monocytes in the control and Escherichia coli LPS-treated rabbits. Values represent mean \pm SEM for $n=6$ rabbits.

Recuento total de leucocitos, neutrófilos, linfocitos y monocitos en conejos control y tratados con lipopolisacárido de Escherichia coli. Valores representan el promedio \pm EEM para $n=6$ conejos. 
Table 1. Mean values $(n=6)$ of packed cell volume, platelet counts, concentrations of total proteins and albumin in the control and Escherichia coli LPS-treated rabbits.

Promedios de volumen globular, recuento de plaquetas, concentraciones de proteínas totales y albúmina en conejos control y tratados con lipopolisacárido de Escherichia coli.

\begin{tabular}{lcccccccccc}
\hline & \multicolumn{4}{c}{ Control Group } & \multicolumn{4}{c}{ LPS-Treated Group } \\
\cline { 2 - 11 } & \multicolumn{4}{c}{ Time $(\mathrm{h})$} & \multicolumn{4}{c}{ Time (h) } \\
\hline Variable & Basal & 4 & 8 & 12 & 24 & Basal & 4 & 8 & 12 & 24 \\
Packed cell volume (\%) & $35.6 \pm 5.3$ & $36.1 \pm 3.7$ & $35.8 \pm 3.6$ & $36.4 \pm 2.8$ & $35.6 \pm 2.4$ & $37.1 \pm 3.9$ & $35.1 \pm 2.2$ & $32.5 \pm 3.2$ & $34.9 \pm 4.9$ & $35.8 \pm 5.6$ \\
Platelet counts & $549 \pm 51$ & $511 \pm 50$ & $440 \pm 40$ & $433 \pm 36$ & $480 \pm 62$ & $588 \pm 45$ & $326 \pm 30 *$ & $352 \pm 47 *$ & $367 \pm 79$ & $369 \pm 80$ \\
$(\times \mu L)$ & & & & & & & & & & \\
Total Proteins (g/dL) & $6.1 \pm 1.53$ & $6.3 \pm 1.22$ & $6.4 \pm 1.47$ & $6.0 \pm 1.25$ & $6.4 \pm 1.39$ & $6.0 \pm 1.49$ & $6.2 \pm 0.98$ & $6.1 \pm 1.14$ & $6.1 \pm 1.20$ & $5.9 \pm 1.02$ \\
Albumin (g/dL) & $4.3 \pm 1.29$ & $4.3 \pm 0.89$ & $4.7 \pm 1.28$ & $4.2 \pm 1.16$ & $4.6 \pm 1.00$ & $4.0 \pm 0.47$ & $3.9 \pm 1.37$ & $4.1 \pm 0.91$ & $4.1 \pm 0.83$ & $4.6 \pm 1.12$ \\
AST (U/L) & $27.9 \pm 11,5$ & $24.0 \pm 4.5$ & $23.7 \pm 7.1$ & $25.3 \pm 6.4$ & $31.9 \pm 1.1$ & $25.4 \pm 10.6$ & $25.0 \pm 6.9$ & $37.0 \pm 14.734 .1 \pm 10.2$ & $21.7 \pm 9.0$ \\
GGT (U/L) & $5.7 \pm 1.4$ & $9.4 \pm 1.2$ & $11.2 \pm 1.2$ & $7.7 \pm 1.9$ & $6.1 \pm 1.6$ & $8.4 \pm 3.3$ & $4.7 \pm 0.6$ & $10.5 \pm 2.5$ & $8.7 \pm 1.7$ & $5.9 \pm 1.7$ \\
\hline
\end{tabular}

LPS was administered intravenously by two separate injections of $1 \mu \mathrm{g} / \mathrm{kg}$ with intervals of $6 \mathrm{~h}$. Values represent mean $\pm \mathrm{SEM}$ of $\mathrm{n}=6$.

* Significantly different from Basal values $(\mathrm{P}<0.05)$

with an acute answer to an endotoxemic shock (Elmas et al $2006^{\mathrm{a}, \mathrm{b}}$ ). Consequently, the absence of changes in the activity of AST and GGT enzymes observed in the rabbits of current work, indicate that the dose of LPS administered to rabbits was not enough to induce pathological modifications in hepatic cells and it was well tolerated by the animals.

It is concluded that intravenous administration of a low dose of E. coli LPS at $6 \mathrm{~h}$ intervals induces significant physiological and biochemical changes that are characterised by a faster increase in body temperature, similar to previous reports with high doses of LPS. However, the haematological and biochemical modifications were mild, with a lower intensity and shorter duration than those reported in rabbits treated with high doses of LPS. Considering that changes observed had a mild to moderate intensity, they are consistent with an initial state of gram negative infection. It is concluded that injections of repeated doses of $1 \mu \mathrm{g} / \mathrm{kg}$ of LPS evoke an APR that induces changes which are well tolerated by the rabbits.

\section{ACKNOWLEDGEMENTS}

Financial support to carry out this research work was provided by Grant FONDECYT 1130473 from the National Council for Science and Technology (CONICYT-Chile).

\section{REFERENCES}

Andreasen AS, KS Krabbe, R Krogh-Madsen, S Taudorf, BK Pedersen, K Moller. 2008. Human endotoxemia as a model of systemic inflammation. Curr Med Chem 15, 1697-1705.

Burrow GE. 1979. Equine Escherichia coli endotoxemia. Comparison of intravenous and intraperitoneal endotoxin administration. Am J Vet Res 40, 991-998.

Cox G, J Gauldie. 1997. Interluekin-6. In: Remick DG, Friedland JS (eds). Cytokines in health and disease. Marcel Dekker, New York, USA, Pp 81-100
Deldar A, JM Naylor, JC Bloom. 1984. Effects of Escherichia coli endotoxin on leukocyte and platelet counts, fibrinogen concentrations, and blood clotting in colostrum-fed and colostrun-deficient neonatal calves. Am J Vet Res 45, 670-677.

Duncan SG, KM Meyers, SM Reed, B Grant. 1985. Alteration in coagulation and hemograms of horses given endotoxin for 24 hours via hepatic portal infusions. Am J Vet Res 46, 1287-1293.

Ebersole JL, D Cappelli. 2000. Acute-phase reactants in infections and inflammatory diseases. Periodontol 40, 19-49.

Elmas M, E Yazar, K Uney, A Er. 2006ª . Influence of Escherichia coli endotoxin-induced endotoxaemia on the pharmacokinetics of enrofloxacin after intravenous administration in rabbits. J Vet Med Series A 53, 410-414.

Elmas M, E Yazar, K Uney, A Karabach. 2006 ${ }^{\mathrm{b}}$. Pharmacokinetics of flunixin after intravenous administration in healthy and endotoxaemic rabbits. Vet Res Comm 30, 73-81.

Hewett JA, RA Roth. 1993. Hepatic and extrahepatic pathobiology of bacterial lipopolysaccharides. Pharmacol Rev 45, 381-411.

Hodgson JC. 2006. Review: Endotoxin and mammalian host responses during experimental disease. J Comp Pathol 135, 157-175.

Jacobsen S, T Toelboell, P Andersen. 2005. Dose dependency and individual variability in selected clinical, haematological and blood biochemical responses after systemic lipopolysaccharide challenge in cattle. Vet Res 36, 167-178.

Klinger MHF, W Jelkmann. 2002. Role of the blood platelet in infection and inflammation. J Inter Cytok Res 22, 913-922.

Koot M, CTM van Duin, Th Wensing, ASJPAM van Miert. 1989. Comparative observations of fever and associated clinical, haematological and blood biochemical changes after parenteral administration of poly I: poly C, interferon-alpha2a and Escherichia coli endotoxin in goats. Vet Quart 11, 41-50.

Lohuis JACM, JHM Verheijden, C Burvenich, ASJPAM van Miert. 1988. Pathophysiological effects of endotoxins in ruminant. Vet Quart 10, 109-116.

Myers MJ, DE Farrel, DC Palmer, LO Post. 2003. Inflammatory mediator production in swine following endotoxin challenge with or without co-administration of dexamethasone. Int Immunopharmacol 3, 571-579.

Parker SJ, PE Watkins. 2001. Experimental models of gram-negative sepsis. Brit J Surg 88, 22-30.

Raetz CRH, C Whitfield. 2002. Lipopolysaccharide endotoxins. Annu Rev Biochem 71, 635-700.

Roth RA, JR Harkema, JP Pestka, PE Ganey. 1997. Is exposure to bacterial endotoxin a determinant of susceptibility to intoxication fron xenobiotic agents?. Toxicol Appl Pharm 147, 300-311. 
Roth J, Ch Rummel, SW Barth, R Gerstberger, T Hübschle. 2006. Molecular aspects of fever and hyperthermia. Neurologic Clinics 24, 421-429.

Saitoh T, E Kokue, M Shimoda. 1999. The suppressive effects of lipopolysaccharide-induced acute phase response on hepatic cytochrome $\mathrm{P} 450$-dependent drug metabolism in rabbits. $J$ Vet Pharmacol Ther 22, 87-95. van Miert ASJPAM. 1990. Influence of febrile disease on the pharmacokinetics of veterinary drugs. Ann Rech Vet Supplement $1,21 \mathrm{~S}-28 \mathrm{~S}$

Ward DS, JF Fessler, GD Bottoms, J Turek. 1987. Equine endotoxemia: Cardiovascular, eicosanoid, hematologic, blood chemical, and plasma enzyme alterations. Am J Vet Res 48, 1150-1156. 